\title{
Uncovering hidden specific diversity of Andean glassfrogs of the Centrolene buckleyi species complex (Anura: Centrolenidae)
}

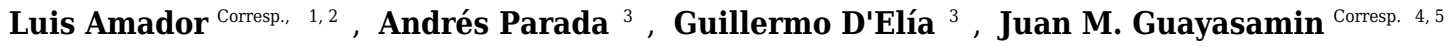 \\ 1 Doctorado en Ciencias mención Ecología y Evolución, Universidad Austral de Chile, Valdivia, Chile \\ 2 Departamento de Investigación Científica, Universidad Laica Vicente Rocafuerte de Guayaquil, Guayaquil, Ecuador \\ 3 Instituto de Ciencias Ambientales y Evolutivas ICAEV, Universidad Austral de Chile, Valdivia, Chile \\ 4 Instituto BIÓSFERA-USFQ, Laboratorio de Biología Evolutiva, Colegio de Ciencias Biológicas y Ambientales COCIBA, Universidad San Francisco de Quito, \\ Quito, Ecuador \\ ${ }^{5}$ Centro de Investigación de la Biodiversidad y Cambio Climático, Ingeniería en Biodiversidad y Recursos Genéticos, Facultad de Ciencias del Medio \\ Ambiente, Universidad Tecnológica Indoamérica, Quito, Ecuador \\ Corresponding Authors: Luis Amador, Juan M. Guayasamin \\ Email address: amadoroyola@gmail.com, jmguayasamin@gmail.com
}

The glassfrog Centrolene buckleyi has been recognized as a species complex. Herein, using coalescence-based species delimitation methods, we evaluate the specific diversity within this taxon. Four coalescence approaches (GMYCs, bGMYC, PTP, and bPTP) were consistent with the delimitation results, identifying four lineages within what is currently recognized as $C$. buckleyi. We propose three new candidate species that should be tested with nuclear markers, morphological and behavioural data. In the meantime, for conservation purposes, candidate species should be considered evolutionary significant units, in light of observed population crashes in the $C$. buckleyi species complex. Finally, our results support the validity of $C$. venezuelense, formerly considered as a subspecies of C. buckleyi. 
1 Uncovering hidden specific diversity of Andean glassfrogs of the Centrolene buckleyi

2 species complex (Anura: Centrolenidae)

3 Luis Amador 1, 2, *, Andrés Parada³, Guillermo D’Elía³, Juan M. Guayasamin 4, 5, *

$4{ }^{1}$ Doctorado en Ciencias mención Ecología y Evolución, Facultad de Ciencias, Universidad

5 Austral de Chile, Valdivia, Chile. Email address: amadoroyola@gmail.com

$6{ }^{2}$ Departamento de Investigación Científica, Universidad Laica Vicente Rocafuerte, Avenida Las

7 Américas, Guayaquil, Ecuador

$8{ }^{3}$ Instituto de Ciencias Ambientales y Evolutivas ICAEV, Facultad de Ciencias, Universidad 9 Austral de Chile, Valdivia, Chile.

$10{ }^{4}$ Instituto BIÓSFERA-USFQ, Laboratorio de Biología Evolutiva, Colegio de Ciencias

11 Biológicas y Ambientales COCIBA, Universidad San Francisco de Quito USFQ, Campus

12 Cumbayá, Casilla Postal 17-1200-841, Quito 170901, Ecuador

$13{ }^{5}$ Centro de Investigación de la Biodiversidad y Cambio Climático, Ingeniería en Biodiversidad y

14 Recursos Genéticos, Facultad de Ciencias del Medio Ambiente, Universidad Tecnológica

15 Indoamérica, Calle Machala y Sabanilla, Quito, Ecuador

16 *Corresponding Author: amadoroyola@gmail.com, jmguayasamin@gmail.com

17 Short title: Species delimitation of Andean glassfrogs 


\section{Abstract}

19 The glassfrog Centrolene buckleyi has been recognized as a species complex. Herein, using 20 coalescence-based species delimitation methods, we evaluate the specific diversity within this 21 taxon. Four coalescence approaches (GMYCs, bGMYC, PTP, and bPTP) were consistent with

22 the delimitation results, identifying four lineages within what is currently recognized as $C$.

23 buckleyi. We propose three new candidate species that should be tested with nuclear markers,

24 morphological and behavioural data. In the meantime, for conservation purposes, candidate 25 species should be considered evolutionary significant units, in light of observed population 26 crashes in the $C$. buckleyi species complex. Finally, our results support the validity of $C$. 27 venezuelense, formerly considered as a subspecies of C. buckleyi.

\section{Introduction}

29 Species delimitation — the process by which species boundaries are determined — is important 30 and a challenge for characterizing the biota of biodiversity hotspots (Myers et al., 2000).

31 Achieving a taxonomic scheme that reflects the evolutionary history of organisms is critical for

32 both theoretical (characterizing biodiversity) and practical (designing conservation strategies)

33 reasons (e.g. Esselstyn et al., 2012). Although species delimitation ideally uses multiple lines of 34 evidence (Padial et al., 2010), DNA sequences play an important role in species-level lineage 35 identification (Chambers \& Hebert, 2016; Pentinsaari, Vos \& Mutanen, 2017). Sequences have 36 been recently, and more frequently, analyzed under coalescent-based methods (e.g. Pons et al., 37 2006; Yang \& Rannala, 2010; Camargo et al., 2012; Reid \& Carstens, 2012; Fujisawa \&

38 Barraclough, 2013; Zhang et al., 2013). The main goal of coalescent-based species delimitation 39 is to identify evolutionarily independent lineages, where each lineage represents a single species 
40 (Fujita et al., 2012; for the conceptualization of the species category, in the so called Generalized

41 Lineage Concept, see de Queiroz, 1998, 1999, 2007). Coalescent-based methods, which allow

42 testing alternative hypotheses on the divergence of a lineage, are expected to reduce the

43 subjective bias introduced by researchers, avoiding using ad hoc thresholds (i.e., degree of

44 morphological, ecological, and/or percentage of sequence divergence) as criteria to establish

45 species limits. As such, these methods have become a common tool for delimiting species, both

46 to propose candidate species as well as to describe new species (e.g., Leaché \& Fujita, 2010;

47 Páez-Moscoso \& Guayasamin, 2012; Crivellaro et al., 2018). However, these sequences-based

48 methods have several assumptions that must be met (see Carstens et al., 2013; Talavera, Dincă \&

49 Vila, 2013; White et al., 2014), as well as limitations and drawbacks according to the

50 characteristics of the analyzed data, including erroneous results with species of recent

51 diversification (Wei et al., 2016; Jacobs et al., 2018), and species diversity overestimation

52 (Sukumaran \& Knowles, 2017). Therefore, conclusive species delimitation studies must have an

53 integrative approach (Dayrat, 2005; Padial et al., 2010).

54 Proposing candidate species, which currently is mostly done on the basis of molecular evidence

55 (e.g., Correa et al., 2017; Hurtado \& D’Elía, 2018; Lin, Stur \& Ekrem, 2018) can guide future

56 taxonomic research, allowing one to direct the costlier efforts (e.g., field collections,

57 morphological assessment of large specimen series) to specific taxonomic and geographic areas

58 of interest. In turn, these efforts result in an acceleration of the discovery and validation of new

59 species (Dellicour \& Flot, 2015; Vitecek et al., 2017), which is relevant in the current era of

60 biodiversity crisis. In addition, candidate species can be considered evolutionary significant

61 units, which in turn can be subject to conservation actions (Moritz, 1994). 
62 The taxon Centrolene buckleyi (Boulenger, 1882) has a large distribution inhabiting montane

63 primary and secondary forests in high tropical Andean zones (1,900-3,300 msnm), as well as

64 inter-Andean scrubland and Páramo environments of Colombia, Ecuador, and northern Peru

65 (Duellman \& Wild, 1993; Guayasamin et al., 2006; Rada \& Guayasamin, 2008; Guayasamin \&

66 Funk, 2009) (Fig. 1). The glassfrog C. buckleyi has a relatively simple taxonomic history; only

67 two taxonomic forms, venezuelense (Rivero, 1968) and johnelsi (Cochran \& Goin, 1970), are

68 associated to it. The later was synonymized under C. buckleyi by Ruiz-Carranza \& Lynch

69 (1991). Meanwhile, the form venezuelense was considered as a subspecies of C. buckleyi until it

70 was elevated to species level as C. venezuelense by Myers \& Donnelly (1997), based on the

71 argument that it is highly unlikely that the distribution of $C$. buckleyi, with its type locality in

72 Ecuador, reaches Venezuela. Señaris \& Ayarzaguena (2005) agree in considering venezuelense

73 at the species level, given that it presents morphological and acoustic differences with respect to

74 typical buckleyi. Cisneros-Heredia \& McDiarmid (2007), based on morphological characters,

75 stated that further research is needed to evaluate the distinction of venezuelense from buckleyi.

76 Even after the removal of venezuelense, distinct lines of evidence suggest that as currently

77 understood, C. buckleyi may encompass more than one species. For instance, Colombian

78 populations are regarded as $C$. aff. buckleyi as a way to denote uncertainties in their identity

79 (Guayasamin et al., 2008). Moreover, Guayasamin et al. (2006) identified significant call

80 variation among populations of C. buckleyi; similarly, several studies have shown the lack of

81 monophyly for this taxon (Guayasamin et al., 2006, 2008; Guayasamin \& Funk, 2009; Pyron \&

82 Wiens, 2011; Castroviejo-Fisher et al., 2014; Twomey, Delia \& Castroviejo-Fisher, 2014). As

83 such, in current catalogues (e.g., Guayasamin et al., 2017) C. buckleyi is regarded as a species

84 complex. 
85 Given these antecedents, herein, using an expanded molecular dataset, and phylogenetic and 86 coalescent-based species delimitation analyses, we evaluate the species limits of populations

87 currently allocated to the taxon C. buckleyi. Our study identifies four distinctive lineages, three

88 of which should be considered as candidate species.

\section{Materials \& Methods}

90 A total of 34 sequences of the $12 \mathrm{~S}$ and $16 \mathrm{~S}$ mitochondrial genes of the genus Centrolene were

91 analysed; of these, ten belong to the Centrolene buckleyi species complex. The outgroup was

92 formed with sequences of Nymphargus, a genus closely related to Centrolene (Guayasamin et al.,

93 2008; Castroviejo-Fisher et al., 2014; Twomey, Delia \& Castroviejo-Fisher, 2014). As such, the

94 analysed matrix totaled 47 sequences (see Table S1). Sequences were downloaded from

95 Genbank or gathered by us (Tables 1, S1). The matrix includes sequences of the C. buckleyi

96 species complex from four localities throughout its distributions in the eastern Andean foothills

97 of Ecuador (Table 1; Fig. 1). Specimen collection was done under research permit (MAE-DNB-

98 CM-2015-0017) issued by the Ministerio del Ambiente of Ecuador (MAE). Additionally,

99 morphological characters of all specimens were examined by one of the authors (JMG).

\section{DNA extraction and sequencing}

101 For newly generated sequences, genomic DNA was extracted from 96\% ethanol-preserved

102 muscle tissue samples using a modified salt precipitation method based on the Puregene DNA

103 purification kit (Gentra Systems). We amplified two mitochondrial genes 12S and 16S using the

104 primers t-Phe-frog and t-Val-frog developed by Wiens et al. (2005). PCR reactions follow the 105 protocol described by Guayasamin et al. (2008). Cycle sequencing reactions were performed by 
106 Macrogen Labs (Macrogen Inc., Korea). All fragments were sequenced in both forward and

107 reverse directions with amplification primers. Sequences were deposited in GenBank (Tables 1, 108 S1).

109 Phylogenetic analyses

110 Four matrices were created; a single matrix with $12 \mathrm{~S}$, a single matrix with $16 \mathrm{~S}$, concatenation of

111 both fragments (these three matrices included all sequences Centrolene + outgroup), and one

112 matrix formed only by sequences of Centrolene (34 terminals concatenated with 12S-16S

113 mtDNA genes). Sequences were aligned in MAFFT v7 under an automatic strategy (Katoh \&

114 Standley, 2013). The aligned matrix was imported into Aliview (Larsson, 2014), where segments

115 that presented ambiguous alignments were excluded. All positions containing only gaps were

116 deleted. The best nucleotide substitution model was selected with ModelFinder

117 (Kalyaanamoorthy et al., 2017) using the Bayesian information criterion (BIC) and was the same

118 for the first three data sets with all sequences of Centrolene + Nymphargus (TIM2 $+\mathrm{I}+\mathrm{G})$. For

119 the matrix with only sequences belonging to Centrolene the selected best model was TIM2 + R3.

120 This last data set was used to infer the input genealogy in species delimitation analysis. The first

121 three were used to conduct phylogenetic analyses.

122 Phylogenetic trees were obtained using Maximum Likelihood (ML) and Bayesian inference (BI).

123 ML trees were inferred in IQ-TREE (Nguyen et al., 2015); nodal support was assessed with

1241,000 ultrafast bootstrap replicates (Minh, Nguyen \& Haeseler, 2013). Bayesian inference

125 analyses were conducted with MrBayes 3.2 (Ronquist et al., 2012) using two parallel runs of four

126 Markov chains that were allowed to run for ten million generations and that were sampled every

1271,000 generations. The first $25 \%$ of the sampled trees were discarded as a burnin, prior to 
128 constructing a consensus tree with the remaining sample. Phylogenetic trees were visualized

129 using FigTree 1.4.3 (http://tree.bio.ed.ac.uk/software/figtree/). Clades with ML values (BV)

130 equal or above $75 \%$ and posterior probabilities values (PP) equal or greater than 0.95 were

131 considered as strongly supported. MEGA 7.0 (Kumar, Stecher \& Tamura, 2016) was used to

132 estimate genetic distances between sequences of the $16 \mathrm{~S}$ gene with a bootstrap procedure of 1331,000 replicates.

\section{Methods for delimiting species}

135 We used two coalescence based methods, and their Bayesian implementation, to delimit species 136 on the basis of variation of $12 \mathrm{~S}$ and $16 \mathrm{~S}$ sequences.

137 Generalized Mixed Yule Coalescent (GMYC) and Bayesian General Mixed Yule-Coalescent

138 (bGMYC). -- The GMYC method uses maximum likelihood statistics and takes an estimated

139 ultrametric and bifurcating genealogy from a single-locus as input (Pons et al., 2006; Fujisawa \&

140 Barraclough, 2013). The time calibrated-ultrametric tree was obtained with BEAST 2 (Bouckaert

141 et al., 2014) using the temporal calibration scheme outlined by Castroviejo-Fisher et al. (2014)

142 for the most recent common ancestor (MRCA) of Centrolene and Nymphargus. We conducted

143 two independent analyses to check for consistency in the results under a relaxed clock model and

144 a birth-death model of speciation. Each analysis was run for 20 million generations logging

145 every 1,000 generations. BEAST log files were checked for convergence and for ESS values

146 above 200 using Tracer v1.6 (Rambaut, Suchard \& Drummond, 2014). Maximum clade

147 credibility tree was estimated with TreeAnnotator v2 (distributed as part of BEAST) with the

148 sampled trees after discarding the first $25 \%$ as burn-in. Outgroups were removed with

149 drop.tip.simmap function of R v. 3.3.2 (R Core Team, 2016) package phytools (Revell, 2012). 
150 The GMYC method attempts to model the transition point between cladogenesis (Yule process)

151 and the population level process of allelic coalescence, using the assumption that cladogenesis

152 will occur at a much lower rate than coalescence (Carstens et al., 2013; Tang et al., 2014).

153 GMYC was fitted to the ultrametric gene tree to delimit the species boundaries using single

154 (GMYCs, Pons et al., 2006) and multiple threshold models (GMYCm, Monaghan et al., 2009).

155 We compared the likelihood of single and multiple transition model with likelihood of null

156 model via a likelihood ratio test. These analyses were performed with the package Splits (Ezard,

157 Fujisawa \& Barraclough, 2009) in R, after removing zero-length branches and making the tree

158 fully dichotomous. We also performed a Bayesian General Mixed Yule-Coalescent (bGMYC)

159 analysis (Reid \& Carstens, 2012), which takes into account the uncertainties in the estimation of

160 the genealogy. The analysis was done with the R package bGMYC (Reid \& Carstens, 2012) in

$161 \mathrm{R}$, which calculates the posterior marginal probabilities of species boundaries. This was

162 performed with a post-burn-in sample of 100 trees sampled from the posterior distribution of

163 trees. For the bGMYC analysis, the priors of parameters t1 and t2 were set at 4 and 100,

164 respectively. The bGMYC analysis was performed with 50,000 generations, with a burnin of

$16510 \%$, and a thinning interval of 1,000 samples.

166 Poisson Tree Processes (PTP) and Bayesian Poisson Tree Processes (bPTP) methods. --This

167 method models speciation and coalescence events in terms of numbers of substitutions (Zhang et

168 al., 2013). PTP provides hypothesis of species delimitation based on a gene tree (not necessarily

169 ultrametric), using heuristic algorithms to identify the most likely classification of branches in

170 processes at the level of populations and species (Tang et al., 2014). We also used bPTP, which

171 is the Bayesian implementation and updated version of the PTP method. Moreover, the result of

172 the search for the maximum probability in PTP is part of the results of bPTP. This 
173 implementation produces Bayesian posterior probability values (PPV) of delimited species using

174 as input the phylogenetic tree (the same as in PTP). A higher Bayesian value (PPV $>0.90)$ at one

175 node indicates that all descendants of that node are more likely to belong to the same species

176 (Zhang et al., 2013). The PTP and bPTP analyses were performed on the web server

177 http://species.h-its.org/ptp/.

178 To discern among incongruent results of the species delimitation analyses, we followed the

179 reasoning of Carstens et al. (2013), relying on those delimitations schemes that are recovered in

180 the majority of the analyses.

\section{Results}

\section{Phylogenetic relationships}

183 The alignment of 47 nucleotide sequences, including the outgroups, resulted in a total of 1,641

184 positions in the final dataset. All new sequences were deposited in GenBank. The methods of

185 phylogenetic reconstruction (ML and $\mathrm{BI}$ ) inferred identical evolutionary relationships, in

186 particular regarding the lineages of the Centrolene buckleyi species complex (Fig. 2).

187 The Centrolene buckleyi species complex is not recovered as monophyletic; sequences recovered

188 from specimens of $C$. buckleyi form four main lineages, namely C. buckleyi sensu stricto, $C$.

189 buckleyi [Ca1], C. buckleyi [Ca2] and C. aff. buckleyi [Ca3] (Fig. 2). Specimens of the first

190 lineage come from the proximities of the type locality of Centrolene buckleyi (Intag, Imbabura

191 province, Ecuador), as such, hereafter we refer to the first lineage as C. buckleyi sensu stricto.

192 This form is sister to C. ballux in a strongly supported clade (BV=99\%, $\mathrm{PP}=1)$; C. buckleyi [Ca1]

193 is sister to $C$. sabini $(\mathrm{BV}=84 \%, \mathrm{PP}=0.98)$, while $C$. buckleyi $[\mathrm{Ca} 2$ ] is sister to a clade formed by 
194 C. venezuelense and $C$. aff. buckleyi [Ca3] from Colombia in a highly supported clade $195 \quad(\mathrm{BV}=96 \%, \mathrm{PP}=1)$ (Fig. 2).

196 Molecular species delimitation

197 The results obtained with the GMYCs approach, delimited 26 putative species of the matrix of 19834 sequences of Centrolene; recognizing $C$. buckleyi sensu stricto, C. venezuelense, $C$. aff. 199 buckleyi [Ca3], C. buckleyi [Ca1] and C. buckleyi [Ca2] as different species (Fig. 3, see also Fig. 200 S1). The two specimens of C. buckleyi sensu stricto (KU17803, Cuicocha Lake, Imbabura 201 province, and MZUTI763, Oyacachi-El Chaco road, Napo province; distance between locations: 202 about $60 \mathrm{~km}$ ) were clustered in a single lineage. Similarly, the two specimens of C. buckleyi 203 [Ca1] (MRy547 and MRy548, Shucos, Zamora Chinchipe province) and the three individuals of 204 C. buckleyi [Ca2] (MZUTI83 - MZUTI85, Yanayacu, Napo province) were clustered in a single 205 lineage, respectively. Furthermore, the two specimens of $C$. venezuelense were grouped in a 206 single lineage as well as $C$. aff. buckleyi $[\mathrm{Ca} 3]$ was recovered as a different candidate species. 207 Meanwhile the GMYCm approach found 21 species, GMYCm was the only one of the species 208 delimitation methods that yielded distinct delimitation results, greatly departing from the results 209 of the other analyses (Fig. S2). For instance, GMYCm separated the three specimens of $C$.

210 buckleyi [Ca2] into two different species, while consolidating $C$. buckleyi sensu stricto and $C$.

211 ballux as a single species; similarly, C. venezuelense and C. aff buckleyi [Ca3] that were

212 recovered as a single entity. For both methods (GMYCs and GMYCm), the result of Likelihood 213 ratio test was not significant $\left(\mathrm{LRtest}_{\mathrm{SINGLE}}=0.063, \mathrm{LRtest}_{\mathrm{MULTIPLE}}=0.058\right)$ and the likelihood

214 value of the GMYC model was always higher at both methods, single and multiple $\left(\mathrm{ML}_{\mathrm{SINGLE}}=\right.$ $\left.215202.026, \mathrm{ML}_{\mathrm{MULTIPLE}}=202.117\right)$ than the value of the likelihood of null model $(\mathrm{L}=199.268)$. 
216 The Bayesian implementation of the method (bGMYC) also delimited 26 putative species, the

217 same that were recovered with GMYCs (Fig. 3, see also the Klee diagram in Fig. S3).

218 The ML implementation of PTP and the Bayesian implementation of the method (bPTP),

219 considered the topology recovered with MrBayes as a guide tree. These methods delimited 26

220 putative species with good support, recovering the same delimitation results obtained with

221 GMYC and bGMYC (Figs. 3 and S4). Further details of the results of the analysis of species

222 delimitation are in Supplementary Information.

223 Average genetic distances of the $16 \mathrm{~S}$ matrix, within and between candidate species pairs of the

224 C. buckleyi species complex are presented in Table S2. The maximum values between candidate

225 species were observed for the comparison between C. buckleyi [Ca1] with C. buckleyi sensu

226 stricto and C. buckleyi [Ca2] (1.6\% and 1.8\% respectively); while the lower values correspond to

227 the comparisons between $C$. venezuelense with $C$. buckleyi [Ca2] and C. aff. buckleyi [Ca3]

$228(0.7 \%$ and $0.4 \%$ respectively). It is also worth highlighting the low values recovered between $C$.

229 buckleyi sensu stricto with its sister taxa C. ballux (0.6\%) and C. buckleyi [Ca1] with its sister

230 taxa C. sabini $(0.4 \%)$.

\section{Discussion}

232 Centrolene buckleyi has been suggested to represent a species complex, requiring therefore, a 233 taxonomic revision (Guayasamin et al., 2006; Cisneros-Heredia \& McDiarmid, 2007; Hutter, 234 Guayasamin \& Wiens, 2013; Castroviejo-Fisher et al., 2014), which in turn would have direct 235 consequence on conservation status and strategies (the C. buckleyi species complex is currently 236 listed as Vulnerable by IUCN; Guayasamin, 2010). 
237 In this study, we find four distinct lineages within the buckleyi species complex and corroborate

238 the distinction of C. venezuelense (but see the results of the GMYCm analysis, Fig. 3). Within

239 the current taxonomic definition of $C$. buckleyi, we propose three candidate species (namely $C$.

240 buckleyi [Ca1], C. buckleyi [Ca2] and $C$. aff. buckleyi [Ca3]) in addition to the typical form (C.

241 buckleyi sensu stricto). This scenario is supported by phylogenetic (ML, BI) and coalescence-

242 based species delimitation analyses (GMYC, PTP). The ML and BI analyses resulted in a tree

243 with topology similar to those of previous studies on glassfrogs (e.g. Hutter, Guayasamin \&

244 Wiens, 2013; Castroviejo-Fisher et al., 2014; Delia, Bravo-Valencia \& Warkentin, 2017), but

245 with an increased sampling within the $C$. buckleyi species complex. In all phylogenetic analyses

246 performed in this study, C. buckleyi is not recovered as monophyletic; specimens allocated to

247 this taxon fall into four main lineages: C. buckleyi sensu stricto, C. buckleyi [Ca1], C. buckleyi

248 [Ca2] and C. aff. buckleyi [Ca3], which are not closely related (except for C. buckleyi [Ca2] and

249 C. aff. buckleyi [Ca3], which are recovered in the same clade with C. venezuelense in ML and BI

250 analysis). These lineages, instead, are recovered as sister to distinct glassfrog species ( $C$.

251 buckleyi sensu stricto - C. ballux, C. buckleyi [Ca1] - C. sabini, and C. aff. buckleyi [Ca3] - C.

252 venezuelense, respectively). Therefore, the topologies obtained here suggests that there are at

253 least four species in the C. buckleyi species complex. We acknowledge, however, that the

254 observed lack of monophyly of the C. buckleyi species complex at the mitochondrial genome

255 may be a case of differences between gene and species trees, which may be caused by distinct

256 biological processes, such as mitochondrial DNA introgression. This process has been suggested

257 for cases of other amphibians such as the Nearctic treefrogs of the genus Dryophytes (Bryson et

258 al., 2010, 2014) and the toads of the genus Rhinella (Sequeira et al., 2011). However, without

259 nuclear DNA data we cannot test if the mitochondrial-based tree inferred for the C. buckleyi 
260 species complex departs from the species tree; as such, we have no reasons to reject these data

261 and assume they represent the true evolutionary history of the group.

262 Coalescent-based species delimitation methods provide hypotheses for the delimitation of 263 species based on gene trees inferred from DNA sequences (Fujita et al. 2012). Previous studies

264 have reported the congruence in the results of methods such as GMYC and PTP when defining 265 putative species (Lang, Bocksberger \& Stech, 2015; Thormann et al., 2016; Conte-Grand et al., 266 2017). Although GMYC and PTP differ in assumptions (e.g., GMYC uses an ultrametric tree and 267 in PTP it is not required), we obtained similar results with both methods. In fact, most of the 268 used species delimitation methods agree in considering Centrolene buckleyi as a species complex composed of at least four independently evolving lineages. GMYC provided consistent diversity estimates for BEAST trees (Talavera, Dincă \& Vila, 2013; Tang et al., 2014). This method gives

271 better results when the guide tree is well supported; otherwise it may tend to overestimate (or

272 underestimate) the number of candidate species (Fujisawa \& Barraclough, 2013; Leavitt, Moreau

273 \& Lumbsch, 2015). In addition, GMYC is generally stable in the presence of a certain number of 274 singletons, as is our case (Monaghan et al., 2009; Pons et al., 2006). The results of GMYC with 275 multiple threshold (which searches for more than one probable scenario of speciation) gave a 276 smaller number of candidate species that the other methods; when the GMYC method was used 277 with a single threshold (GMYCs), results were in line with those of bGMYC, PTP and bPTP. It 278 should be noted that bGMYC has been successfully applied in other studies that examined 279 species delimitation in amphibians (Lawson et al., 2015; De Andrade et al., 2016), however, this 280 method could also fail due to errors associated with unilocus data (e.g., selection, error in gene 281 tree estimation, incomplete lineage sorting; Satler, Carstens \& Hedin, 2013). Both PTP 282 approaches, ML-PTP and bPTP (adding Bayesian PPV) gave exactly the same result; these 
283 methods simultaneously inferring speciation events based on change in the number of

284 substitutions in the internal nodes (Zhang et al., 2013). When visualizing the likelihood plot of

285 each delimitation method, we observed that the MCMC chains converged, which suggests that

286 the PTP results are reliable (Fig. S5). In bPTP, high values of Bayesian support were obtained,

287 which were calculated as the number of occurrences of all the descendants under a particular

288 node, and are the posterior probabilities that these taxa form a single species under the PTP

289 model (Zhang et al., 2013).

290 The results obtained with the methods GMYC and PTP are consistent; however, this scheme

291 should be viewed with caution, mainly due to intrinsic factors of the mitochondrial genes (e.g.

292 smaller genome size, high mutation rates), to the sampling coverage of the taxa, and to the time

293 of divergence between taxa (Talavera, Dincă \& Vila, 2013; Luo et al., 2018), which could regard

294 intraspecific structure as distinct species (Satler, Carstens \& Hedin, 2013; Sukumaran \&

295 Knowles, 2017). For instance, there are results (not within the Centrolene buckleyi species

296 complex) that are clearly erroneous, such as the union into a single lineage of two

297 morphologically distant species (C. charapita and C. geckoideum) with GMYCm method.

298 Therefore, it is also vital to evaluate these molecular species delimitation methods in light of

299 other sources of data (e.g., morphological distinctiveness).

300 One of the main limitations of our study is that our genetic sampling covers only a fraction of the

301 historical distribution range of the Centrolene buckleyi species complex. The limited sampling is

302 consequence of population crashes observed across distributional range of this species complex.

303 For instance, Bustamante et al. (2005) mentioned that $C$. buckleyi has disappeared or is rarely

304 found at localities where it used to be abundant. Similarly, Guayasamin et al. (2006) carried out 
305 intensively fieldwork in Yanayacu during three years and only found three individuals of what 306 we recognize as C. buckleyi [Ca2]. Finally, historically C. buckleyi has been reported in several

307 localities and different vegetation formations in 10 different provinces of Ecuador; however,

308 only four populations had been recorded between the years 1997 and 2007 (Cisneros-Heredia \&

309 McDiarmid, 2007). Two of these populations correspond to the candidate species that we

310 propose herein (C. buckleyi [Ca1] and C. buckleyi [Ca2]). Thus, in the scenario of widespread

311 population declines, our findings of distinct independently evolving lineages within the $C$.

312 buckleyi species complex make a strong case for increasing efforts aimed to avoid their

313 disappearance.

314 Here we show the existence of candidate species in the Centrolene buckleyi species complex.

315 Although the morphology of all candidate species matches the description of C. buckleyi, calls

316 from the so far studied candidate species are different (see Guayasamin et al., 2006). This

317 observation matches the fact that calls of populations from the Cordillera Occidental of

318 Colombia, approximately 180 kilometers west of the locality of $C$. aff. buckleyi [Ca3] (Bolívar,

319 Grant \& Osorio, 1999) and those of C. buckleyi [Ca2] (Yanayacu Biological Station (YBS) in

320 northeast of Ecuador) are different. Guayasamin et al. (2006) found that the call of C. buckleyi

321 [Ca2] in YBS consisted of 1-5 notes and fundamental frequency $=4,139 \mathrm{~Hz}$ which is

322 considerably distinct from that of specimens from Colombia that consists of a single note and

323 fundamental frequency $=5,200 \mathrm{~Hz}$.

324 It is worth noting that, in some cases, genetic differentiation between species pairs is not related

325 with geographic distance. For example, despite the large geographic gap separating the analyzed

326 populations of $C$. buckleyi [Ca2] with those of $C$. venezuelense and $C$. aff. buckleyi [Ca3] 
327 (approximately $1300 \mathrm{~km}$ and $700 \mathrm{~km}$, respectively; see Table 1), the genetic differences for the

$32816 \mathrm{~S}$ matrix are low $(0.7 \%$ and $0.9 \%)$. The same pattern is seen for C. sabini and C. buckleyi

$329[\mathrm{Ca} 1]$ that have a very low genetic distance (0.4\%) and approximately $1300 \mathrm{~km}$ of geographic

330 distance. On the other hand, for the pair C. buckleyi sensu stricto and C. buckleyi [Ca2], whose

331 populations in the cloud forests of the Ecuadorian Napo province, are separated by only $45 \mathrm{~km}$,

332 present a large genetic distance than the previous comparisons (1.4\%). Moreover, in general,

333 sister species of Centrolene show low levels of genetic divergence. For example, between $C$.

334 altitudinale and C. notostictum there is a divergence of $0.7 \%$, a similar low value $(0.6 \%)$ is found

335 between $C$. huilense and C. muelleri (CORBIDI 14667) (see Table S2), these two last sister

336 species were recovered as a single species by the GMYCm method. It has been suggested that

337 most speciation events of Centrolene occurred during the last five million years, mostly mediated

338 by the Andes uplift (Lynch \& Duellman, 1997; Hutter, Guayasamin \& Wiens, 2013; Castroviejo-

339 Fisher et al., 2014). This rapid and recent speciation could explain both the low genetic

340 differences found among species, as well as the little morphological divergence observed in the

341 C. buckleyi species complex. A similar pattern has been observed in the plump toad

342 Osornophryne bufoniformis, another high-Andean anuran species distributed in the northern

343 Andes of Ecuador and Colombia, where highland species also exhibit shallow genetic

344 differentiation (Páez-Moscoso \& Guayasamin, 2012).

345 Some of the candidate species that are suggested in our study (Fig. 3) seem to be separated by

346 well-characterized biogeographic barriers. For example, C. sabini (Kosñipata valley, Cusco

347 Department, Peru) and C. buckleyi [Ca1] (Zamora Chinchipe, southern Ecuador) are separated

348 by the Huancabamba Depression, an important geographic barrier delimiting distinct

349 communities of high-Andean amphibians (see Catenazzi et al., 2012; Hutter, Guayasamin \& 
350 Wiens, 2013; Castroviejo-Fisher et al., 2014; Hutter, Lambert \& Wiens, 2017). Another well-

351 supported example of sister species of Andean frogs separated by geographical barriers are

352 rainfrogs of genus Pristimantis, such as $P$. cedros and $P$. pahuma separated by the Guayllabamba

353 River in northern Ecuador (Hutter \& Guayasamin, 2015).

354 The inferences drawn from this study should be taken as conservative when evaluating species

355 boundaries of the Centrolene buckleyi species complex, mainly because our population sampling

356 is relatively low and to the use of single-locus based methods. The hypothesis posed here should

357 be used as a preliminary perspective of species boundaries and not as the only evidence

358 necessary to circumscribe species (Leavitt, Moreau \& Lumbsch, 2015). However, the lack of

359 monophyly of C. buckleyi as currently delimited, constitutes strong evidence of the existence of

360 hidden specific diversity. Having said that, before formalizing any taxonomic change (i.e.,

361 describing and naming any new species), further studies integrating morphological variation, as

362 well more geographical samples, additional behavioural (calls) and genetic data (nuclear

363 markers), are needed to test our taxonomic hypothesis (Olave, Solà \& Knowles, 2014;

364 Sukumaran \& Knowles, 2017).

\section{Conclusions}

366 We highlight that our study is in line with several others showing a pattern of high levels of

367 cryptic diversity in amphibians of tropical South America, including glassfrogs (e.g. Páez-Vacas,

368 Coloma \& Santos, 2010; Funk, Caminer \& Ron, 2012; Hutter \& Guayasamin, 2012, 2015;

369 Gehara et al., 2014; Twomey, Delia \& Castroviejo-Fisher, 2014; Ortega-Andrade et al., 2015;

370 Tarvin et al., 2017). As such, we note, that in this era of biodiversity crisis, it is urgent to

371 increase the rate in which the biodiversity is characterized, taking advantage of new and 
372 traditional tools, but, mainly, by facilitating research, an issue that requires the collaboration of

373 both scientists and governmental authorities that regulate research activities.

\section{Acknowledgements}

375 We thank César Marín, Natalí Hurtado, Ewan Twomey, two anonymous reviewers, and the 376 editors for their valuable comments on an earlier version of this contribution. LA wants to thank 377 Mayra García, Dharma Amador, and Gael Amador for their constant support. Thanks to José

378 Núñez for his advice on analysis of coalescence based species delimitation. 


\section{References}

380 Bolívar W, Grant T, Osorio LA. 1999. Combat behavior in Centrolene buckleyi and other 381 centrolenid frogs. Alytes 16(3-4):77-83.

382 Bouckaert R, Heled J, Kühnert D, Vaughan T, Wu C-H, Xie D, Suchard MA., Rambaut A, 383 384 385 Drummond AJ. 2014. BEAST 2: A Software Platform for Bayesian Evolutionary Analysis. PLoS Computational Biology 10(4):e1003537. DOI: 10.1371/journal.pcbi.1003537

386

387

388

389

390

391

392

393

394

395

396

397

Bryson RW, Nieto-Montes de Oca A, Jaeger JR, Riddle BR. 2010. Elucidation of cryptic diversity in a widespread Nearctic treefrog reveals episodes of mitochondrial gene capture as frogs diversified across a dynamic landscape. Evolution 64(8):2315-2330. DOI: $10.1111 / \mathrm{j} .1558-5646.2010 .01014 . \mathrm{x}$

Bryson RW, Smith BT, Nieto-Montes de Oca A, García-Vázquez UO, Riddle BR. 2014. The role of mitochondrial introgression in illuminating the evolutionary history of Nearctic treefrogs. Zoological Journal of the Linnean Society 172(1):103-116. DOI: 10.1111/zoj.12169

Bustamante MR, Ron SR, Coloma LA. 2005. Cambios en la diversidad en siete comunidades de anuros en los Andes de Ecuador. Biotropica 37(2):180-189.

Camargo A, Avila LJ, Morando M, Sites Jr JW. 2012. Accuracy and precision in species tree estimation: an empirical evaluation of performance in lizards of the Liolaemus darwinii 
group (Squamata: Liolaemidae) under varying sub-sampling designs. Systematic Biology 61(2):272-288. DOI: 10.1093/sysbio/syr105

400 Carstens BC, Pelletier TA, Reid NM, Satler JD. 2013. How to fail at species delimitation. Molecular Ecology 22(17):4369-4383. DOI: 10.1111/mec.12413

402 Castroviejo-Fisher S, Guayasamin JM, Gonzalez-Voyer A, Vilà C. 2014. Neotropical 403

404 diversification seen through glassfrogs. Journal of Biogeography 41(1):66-80. DOI:

Catenazzi A, Von May R, Lehr E, Gagliardi-Urrutia G, Guayasamin JM. 2012. A new, high406

407 elevation glassfrog (Anura: Centrolenidae) from Manu National Park, southern Peru. Zootaxa 3388:56-68.

408

409

410

411

412

413

414

415

416

417 $10.1111 /$ jbi. 12208

Chambers EA, Hebert PDN. 2016. Assessing DNA barcodes for species identification in North American reptiles and amphibians in natural history collections. PLOS ONE 11(4):e0154363. https://doi.org/10.1371/journal.pone.0154363

Cisneros-Heredia DF, McDiarmid RW. 2007. Revision of the characters of Centrolenidae (Amphibia: Anura: Athesphatanura), with comments on its taxonomy and the description of new taxa of glassfrogs. Zootaxa 1572:1-82.

Cochran DM, Goin CJ. 1970. Frogs of Colombia. Bulletin of the United States National Museum 288:1-655.

Conte-Grand C, Britz R, Dahanukar N, Raghavan R, Pethiyagoda R, Tan HH, Hadiaty RK, Yaakob NS, Rüber L. 2017. Barcoding snakeheads (Teleostei, Channidae) revisited: 
Discovering greater species diversity and resolving perpetuated taxonomic confusions. PLoS ONE 12(9):e0184017. https://doi.org/10.1371/journal.pone.0184017

420

421

422

423

424

425

426

427

428

429

430

431

432

433

434

435

436

437

438

Correa C, Vásquez D, Castro-Carrasco C, Zúñiga-Reinoso Á, Ortiz JC, Palma RE. 2017. Species delimitation in frogs from South American temperate forests: The case of Eupsophus, a taxonomically complex genus with high phenotypic variation. PLoS ONE 12(8): e0181026. https://doi.org/10.1371/journal.pone.0181026

Crivellaro MS, Zimmermann BL, Bartholomei-Santos ML, Crandall KA, Pérez-Losada M, Bond-Buckup G, Santos S. 2018. Looks can be deceiving: species delimitation reveals hidden diversity in the freshwater crab Aegla longirostri (Decapoda: Anomura). Zoological Journal of the Linnean Society 182(1):24-37. https://doi.org/10.1093/zoolinnean/zlx030

Dayrat B. 2005. Towards integrative taxonomy. Biological Journal of the Linnean Society 85(3): 407-415. https://doi.org/10.1111/j.1095-8312.2005.00503.x

De Andrade FS, De Magalhaes FDM, Nunes-de-Almeida CH, Veiga-Menoncello ACP, Santana DJ, Garda AA, Loebmann D, Recco-Pimentel SM, Giaretta AA, Toledo LF. 2016. A new species of long-legged Pseudopaludicola from northeastern Brazil (Anura, Leptodactylidae, Leiuperinae). Salamandra 52(2):107-124.

de Queiroz K. 1998. The general lineage concept of species, species criteria, and the process of speciation: A conceptual unification and terminological recommendations. In: Howard DJ, Berlocher SH, eds. Endless forms: Species and speciation. Oxford University Press, New York, 57-75. 
439 de Queiroz K. 1999. The general lineage concept of species and the defining properties of the

440

441

442 de Queiroz K. 2007. Species concepts and species delimitation. Systematic Biology 56(6):879-

443

444

445

446

447

448

449

450

451

452

453

454

455

456

457

458 species category. In: Wilson RA, ed. Species: New interdisciplinary essays. MIT Press, Cambridge, Massachusetts, 49-89.

Delia J, Bravo-Valencia L, Warkentin KM. 2017. Patterns of parental care in Neotropical glassfrogs: fieldwork alters hypotheses of sex-role evolution. Journal of Evolutionary Biology 30(5):898-914. DOI: 10.1111/jeb.13059

Dellicour S, Flot JF. 2015. Delimiting species-poor data sets using single molecular markers: A study of Barcode Gaps, Haplowebs and GMYC. Systematic Biology 64(6):900-908. DOI: $10.1093 /$ sysbio/syu130

Duellman WE, Wild ER. 1993. Anuran Amphibians from the Cordillera de Huancabamba, Northern Peru: systematics, ecology, and biogeography. Occasional Papers of the Museum of Natural History the University of Kansas. Lawrence, Kansas.

Esselstyn JA, Evans BJ, Sedlock JL, Khan FAA, Heaney LR. 2012. Single-locus species delimitation: a test of the mixed Yule-coalescent model, with an empirical application to Philippine round-leaf bats. Proceedings of the Royal Society B: Biological Sciences 279(1743): 3678-3686. http://dx.doi.org/10.1098/rspb.2012.0705

Ezard T, Fujisawa T, Barraclough T. 2009. Splits: SPecies' Limits by Threshold Statistics. Available at http://R-Forge.Rproject.org/projects/splits/(accessed 22 September 2017). 
459 Fujisawa T, Barraclough TG. 2013. Delimiting species using single-locus data and the

460

461

462

463

464

465

466

467

468

469

470

471

472

473

474

475

476

477

478

Generalized Mixed Yule Coalescent (GMYC) approach: a revised method and evaluation on simulated datasets. Systematic Biology 62(5):707-724.

Fujita MK, Leaché AD, Burbrink FT, McGuire JA, Moritz C. 2012. Coalescent-based species delimitation in an integrative taxonomy. Trends in Ecology and Evolution 27(9):480-488. http://dx.doi.org/10.1016/j.tree.2012.04.012

Funk WC, Caminer M, Ron SR. 2012. High levels of cryptic species diversity uncovered in Amazonian frogs. Proceedings of the Royal Society B: Biological Sciences 279(1734):806-1814. DOI: 10.1098/rspb.2011.1653

Gehara M, Crawford AJ, Orrico VGD, Rodríguez A, Lötters S, Fouquet A, Barrientos LS, Brusquetti F, De la Riva I, Ernst R, Gagliardi Urrutia G, Glaw F, Guayasamin JM, Hölting M, Jansen M, Kok PJR, Kwet A, Lingnau R, Lyra M, Moravec J, Pombal Jr JP, Rojas-Runjaic FJM, Schulze A, Señaris JC, Solé M, Rodrigues MT, Twomey E, Haddad CFB, Vences M, Köhler J. 2014. High levels of diversity uncovered in a widespread nominal taxon: continental phylogeography of the Neotropical tree frog Dendropsophus minutus. PLoS ONE 9(9):e103958. DOI: 10.1371/journal.pone.0103958

Guayasamin JM, Bustamante MR, Almeida-Reinoso D, Funk WC. 2006. Glass frogs (Centrolenidae) of Yanayacu Biological Station, Ecuador, with the description of a new species and comments on centrolenid systematics. Zoological Journal of the Linnean Society 147(4):489-513. DOI: 10.1111/j.1096-3642.2006.00223.x 
479 Guayasamin JM, Castroviejo-Fisher S, Ayarzaguena J, Trueb L, Vilá C. 2008. Phylogenetic

480 relationships of glassfrogs (Centrolenidae) based on mitochondrial and nuclear genes.

$481 \quad$ Molecular Phylogenetics and Evolution 48(2):574-595.

482 Guayasamin JM, Frenkel C, Varela-Jaramillo A, Ron SR. 2017. Centrolene buckleyi. In: Ron

483

484

485

486

487

488

489

490

491

492

493

494

495

496

497

498

499

SR, Yanez-Muñoz MH, Merino-Viteri A, Ortiz DA, eds. Anfibios del Ecuador. Version 2018.0. Museo de Zoología, Pontificia Universidad Católica del Ecuador. Available at https://bioweb.bio/faunaweb/amphibiaweb/FichaEspecie/Centrolene\%20buckleyi (accessed 26 February 2018).

Guayasamin JM, Funk WC. 2009. The amphibian community at Yanayacu Biological Station, Ecuador, with a comparison of vertical microhabitat use among Pristimantis species and the description of a new species of the Pristimantis myersi group. Zootaxa 2220:41-66.

Guayasamin JM. 2010. Centrolene buckleyi. The IUCN Red List of Threatened Species 2010: e.T54908A11220443. Available at http://dx.doi.org/10.2305/IUCN.UK.20102.RLTS.T54908A11220443.en (accessed 26 February 2018)

Hurtado N, D'Elía G. 2018. Taxonomy of the long-tailed mouse Oligoryzomys destructor (Sigmodontinae: Oryzomyini) with the designation of neotypes for Hesperomys destructor Tschudi, 1844 and Hesperomys melanostoma Tschudi, 1844. Journal of Zoological Systematics and Evolutionary Research 56(3):1-18. https://doi.org/10.1111/jzs.12232

Hutter CR, Guayasamin JM. 2012. A new cryptic species of glassfrog (Centrolenidae: Nymphargus) from Reserva Las Gralarias, Ecuador. Zootaxa 3257:1-21. 
500 Hutter CR, Guayasamin JM. 2015. Cryptic diversity concealed in the Andean cloud forests: two

501 new species of rainfrogs (Pristimantis) uncovered by molecular and bioacoustic data.

502 Neotropical Biodiversity 1(1):36-59. DOI: 10.1080/23766808.2015.1100376

503 Hutter CR, Guayasamin JM, Wiens JJ. 2013. Explaining Andean megadiversity: the evolutionary

504 and ecological causes of glassfrog elevational richness patterns. Ecology Letters

505 16(9):1135-1144. DOI: 10.1111/ele.12148

506 Hutter CR, Lambert SM, Wiens JJ. 2017. Rapid diversification and time explain amphibian

507 richness at different scales in the Tropical Andes, Earth's most biodiverse Hotspot. The

508 American Naturalist 190(6). DOI: 10.1086/694319

509 Jacobs SJ, Kristofferson C, Uribe-Convers S, Latvis M, Tank DC. 2018. Incongruence in

510 molecular species delimitation schemes: What to do when adding more data is difficult.

511 Molecular Ecology 27(10):2397-2413. DOI: 10.1111/mec.14590.

512 Kalyaanamoorthy S, Minh BQ, Wong TKF, von Haeseler A, Jermiin LS. 2017. ModelFinder:

513 fast model selection for accurate phylogenetic estimates. Nature Methods 14(6):587-589.

$514 \quad$ DOI: $10.1038 /$ nmeth.4285

515 Katoh K, Standley DM. 2013. MAFFT Multiple Sequence Alignment Software Version 7:

516 Improvements in performance and usability. Molecular Biology and Evolution 30(4):772-

517 780. DOI: $10.1093 / \mathrm{molbev} / \mathrm{mst} 010$ 
518 Kumar S, Stecher G, Tamura K. 2016. MEGA7: Molecular Evolutionary Genetics Analysis 519 version 7.0 for bigger datasets. Molecular Biology and Evolution 33(7):1870-1874. DOI:

$520 \quad 10.1093 / \mathrm{molbev} / \mathrm{msw} 054$

521 Lang AS, Bocksberger G, Stech M. 2015. Phylogeny and species delimitations in European 522 Dicranum (Dicranaceae, Bryophyta) inferred from nuclear and plastid DNA. Molecular 523 Phylogenetics and Evolution 92:217-225. https://doi.org/10.1016/j.ympev.2015.06.019

524 Larsson A. 2014. AliView: a fast and lightweight alignment viewer and editor for large data sets. 525 Bioinformatics 30(22):3276-3278. http://dx.doi.org/10.1093/bioinformatics/btu531

526 Lawson LP, Bates JM, Menegon M, Loader SP. 2015. Divergence at the edges: peripatric 527 isolation in the montane spiny throated reed frog complex. BMC Evolutionary Biology

528 15:128. DOI: $10.1186 / \mathrm{s} 12862-015-0384-3$

529 Leaché AD, Fujita MK. 2010. Bayesian species delimitation in West African forest geckos 530 (Hemidactylus fasciatus). Proceedings of the Royal Society of London 277(1697):3071531 3077. http://dx.doi.org/10.1098/rspb.2010.0662

532 Leavitt SD, Moreau CS, Lumbsch HT. 2015. The dynamic discipline of species delimitation: 533 Progress towards effectively recognizing species boundaries in natural populations. In: Upreti DK, Divakar PK, Shukla V, Bajpai R, eds. Recent Advances in Lichenology Volume 2. Springer Press, Berlin, Germany, 11-44. 
536 Lin X-L, Stur E, Ekrem T. 2018. Exploring species boundaries with multiple genetic loci using 537 empirical data from non-biting midges. Zoologica Scripta 47(3):325-341.

538 https://doi.org/10.1111/zsc.12280

539 Luo A, Ling C, Ho SYW, Zhu C. 2018. Comparison of methods for molecular species

540 delimitation across a range of speciation scenarios. Systematic Biology 67(5):830-846.

$541 \quad$ DOI: $10.1093 /$ sysbio/syy011

542 Lynch JD, Duellman WE. 1997. Frogs of genus Eleutherodactylus (Leptodactylidae) in western 543 Ecuador: Systematic, ecology and biogeography. University of Kansas Natural History $544 \quad$ Museum Special Publications 23:1-236.

545 Minh BQ, Nguyen MAT, von Haeseler A. 2013. Ultrafast approximation for phylogenetic 546 bootstrap. Molecular Biology and Evolution 30(5):1188-95. DOI:

$547 \quad 10.1093 / \mathrm{molbev} / \mathrm{mst} 024$

548 Monaghan MT, Wild R, Elliot M, Fujisawa T, Balke M, Inward DJG, Lees DC, Ranaivosolo R, 549 Eggleton P, Barraclough TG, Vogler AP. 2009. Accelerated species inventory on 550 Madagascar using coalescent-based models of species delineation. Systematic Biology 551 58(3):298-311. DOI: 10.1093/sysbio/syp027

552 Moritz C. 1994. Defining 'Evolutionary significant units' for conservation. Trends in Ecology 553 and Evolution 9(10):373-375. DOI: 10.1016/0169-5347(94)90057-4. 
554 Myers CW, Donnelly MA. 1997. A tepui herpetofauna on a granitic mountain (Tamacuari) in the

555 borderland between Venezuela and Brazil: Report from the Phipps Tapirapecó

$556 \quad$ Expedition. American Museum Novitates 3213:1-71.

557 Myers N, Mittermeier RA, Mittermeier CG, da Fonseca GAB, Kent J. 2000. Biodiversity

558 hotspots for conservation priorities. Nature 403(6772):853-858. DOI: 10.1038/35002501

559 Nguyen L-T, Schmidt HA, von Haeseler A, Minh BQ. 2015. IQ-TREE: A fast and effective 560 stochastic algorithm for estimating maximum-likelihood phylogenies. Molecular Biology

561 and Evolution 32(1):268-274. DOI: 10.1093/molbev/msu300

562 Olave M, Solà E, Knowles LL. 2014. Upstream analyses create problems with DNA-based 563 species delimitation. Systematic Biology 63(2):263-271.

$564 \quad$ https://doi.org/10.1093/sysbio/syt106

565 Ortega-Andrade HM, Rojas-Soto OR, Valencia JH, Espinosa de los Monteros A, Morrone JJ,

566 Ron SR, Cannatella DC. 2015. Insights from integrative systematics reveal cryptic

567 diversity in Pristimantis frogs (Anura: Craugastoridae) from the Upper Amazon Basin.

$568 \quad$ PLoS ONE 10(11):e0143392. DOI: 10.1371/journal.pone.0143392

569 Padial J, Miralles A, la Riva I, Vences M. 2010. The integrative future of taxonomy. Frontiers in 570 Zoology 7(1):16. DOI: 10.1186/1742-9994-7-16

571 Páez-Moscoso DJ, Guayasamin JM. 2012. Species limits in the Andean toad genus

572 Osornophryne (Bufonidae). Molecular Phylogenetics and Evolution 65(3):805-22. DOI:

$573 \quad$ 10.1016/j.ympev.2012.08.001. 
574 Páez-Vacas MI, Coloma LA, Santos JC. 2010. Systematics of the Hyloxalus bocagei complex

575 (Anura: Dendrobatidae), description of two new cryptic species, and recognition of $H$. $576 \quad$ maculosus. Zootaxa 2711:1-75

577 Pentinsaari M, Vos R, Mutanen M. 2017. Algorithmic single-locus species delimitation: effects 578 of sampling effort, variation and nonmonophyly in four methods and 1870 species of 579 beetles. Molecular Ecology Resources 17(3):393-404. DOI: 10.1111/1755-0998.12557

580 Pons J, Barraclough TG, Gomez-Zurita J, Cardoso A, Duran D, Hazell S, Kamoun S, Sumlin W, 581 Vogler AP. 2006. Sequence-based species delimitation for the DNA taxonomy of $582 \quad$ undescribed insects. Systematic Biology 55(4):595- 609.

583 Pyron RA, Wiens JJ. 2011. A large-scale phylogeny of Amphibia including over 2800 species, 584 and a revised classification of extant frogs, salamanders, and caecilians. Molecular 585 Phylogenetics and Evolution 61(2):543-583. DOI: 10.1016/j.ympev.2011.06.012

586

587

588 589

590

591

592 593

R Core Team. 2016. R: A language and environment for statistical computing. Vienna, Austria: R Foundation for Statistical Computing. https:/www.R-project.org/.

Rada M, Guayasamin JM. 2008. Redescripción de Cochranella megista (Rivero, 1985) y ampliación de la distribución de nueve ranas de cristal (Anura: Centrolenidae) en Colombia. Papéis Avulsos de Zoologia 48(12):89-101. https://dx.doi.org/10.1590/S0031$\underline{10492008001200001}$

Rambaut A, Suchard MA, Drummond AJ. 2014. Tracer v1.6. Available from http://beast.bio.ed.ac.uk/Tracer. 
594 Reid NM, Carstens BC. 2012. Phylogenetic estimation error can decrease the accuracy of species

595 delimitation: A Bayesian implementation of the general mixed Yule-coalescent model.

596 BMC Evolutionary Biology 12:196. DOI: 10.1186/1471-2148-12-196

597 Revell LJ. 2012. phytools: An R package for phylogenetic comparative biology (and other 598 things). Methods in Ecology and Evolution 3(2):217-223.

599 Rivero JA. 1968. Los Centrolénidos de Venezuela. Memoria de la Sociedad de Ciencias $600 \quad$ Naturales La Salle XXVIII 81:301-334.

601 Ronquist F, Teslenko M, van der Mark P, Ayres DL, Darling A, Höhna S, Larget B, Liu L, 602 Suchard MA, Huelsenbeck JP. 2012. MrBayes 3.2: Efficient Bayesian phylogenetic 603 604 605 606 Ruiz-Carranza PM, Lynch JD. 1991. Ranas Centrolenidae de Colombia I. Propuesta de una nueva clasificacion generica. Lozania. Bogotá 57:1-30.

607 Satler JD, Carstens BC, Hedin M. 2013. Multilocus species delimitation in a complex of 608 morphologically conserved trapdoor spiders (Mygalomorphae, Antrodiaetidae, 609 Aliatypus). Systematic Biology 62(6): 805-823. DOI: 10.1093/sysbio/syt041

Señaris JC, Ayarzagüena J. 2005. Revisión taxonómica de la Familia Centrolenidae (Amphibia: 611 Anura) de Venezuela. Sevilla, Publicaciones del Comité Español del Programa Hombre y Biosfera - Red IberoMaB de la UNESCO. 
613 Sequeira F, Sodré D, Ferrand N, Bernardi JAR, Sampaio I, Schneider H, Vallinoto M. 2011.

614 Hybridization and massive mtDNA unidirectional introgression between the closely

615 related Neotropical toads Rhinella marina and $R$. schneideri inferred from mtDNA and

616 nuclear markers. BMC Evolutionary Biology 11:264. DOI: 10.1186/1471-2148-11-264

617 Sukumaran J, Knowles LL. 2017. Multispecies coalescent delimits structure, not species.

618 Proceedings of the National Academy of Sciences of the United States of America

619 114(7):1607-1612. DOI: 10.1073/pnas.1607921114

620 Talavera G, Dincă V, Vila R. 2013. Factors affecting species delimitations with the GMYC

621 model: insights from a butterfly survey. Methods in Ecology and Evolution 4(12):1101-

622 1110. DOI:10.1111/2041-210X.12107

623 Tang CQ, Humphreys AM, Fontaneto D, Barraclough TG. 2014. Effects of phylogenetic

624 reconstruction method on the robustness of species delimitation using single-locus data.

625 Methods in Ecology and Evolution 5(10):1086-1094. DOI: 10.1111/2041-210X.12246

626 Tarvin RD, Powell EA, Santos JC, Ron SR, Cannatella DC. 2017. The birth of aposematism:

627 High phenotypic divergence and low genetic diversity in a young clade of poison frogs.

628 Molecular Phylogenetics and Evolution 109:283-295.

629 https://doi.org/10.1016/j.ympev.2016.12.035

630 Thormann B, Ahrens D, Marín Armijos D, Peters MK, Wagner T, Wägele JW. 2016. Exploring

631 the leaf beetle fauna (Coleoptera: Chrysomelidae) of an Ecuadorian mountain forest using

632 DNA barcoding. PLoS ONE 11(2):e0148268.

$633 \quad \underline{\text { https://doi.org/10.1371/journal.pone.0148268 }}$ 
634 Twomey EM, Delia J, Castroviejo-Fisher S. 2014. A review of northern Peruvian glassfrogs

635 (Centrolenidae), with the description of four new remarkable species. Zootaxa 3851(1):1-

636 87. https://doi.org/10.11646/zootaxa.3851.1.1

637

638

639

640

641

642

643

644

645

646

647

648

649

650

651

652

Vitecek S, Kučinić M, Previšić A, Živić I, Stojanović K, Keresztes L, Bálint M, Hoppeler F, Waringer J, Graf W, Pauls SU. 2017. Integrative taxonomy by molecular species delimitation: multi-locus data corroborate a new species of Balkan Drusinae microendemics. BMC Evolutionary Biology 17:129. DOI: 10.1186/s12862-017-0972-5

Wei X, McCune B, Lumbsch HT, Li H, Leavitt S, Yamamoto Y, Tchabanenko S, Wei J. 2016. Limitations of species delimitation based on phylogenetic analyses: A case study in the Hypogymnia hypotrypa group (Parmeliaceae, Ascomycota). PLoS ONE 11(11): e0163664. https://doi.org/10.1371/journal.pone.0163664

White BP, Pilgrim EM, Boykin LM, Stein ED, Mazor RD. 2014. Comparison of four speciesdelimitation methods applied to a DNA barcode data set of insect larvae for use in routine bioassessment. Freshwater Science 33(1):338-348.

Wiens JJ, Fetzner JW, Parkinson CL, Reeder TW. 2005. Hylid frog phylogeny and sampling strategies for speciose clades. Systematic Biology 54(5):719-748.

Yang Z, Rannala B. 2010. Bayesian species delimitation using multilocus sequence data. Proceedings of the National Academy of Sciences of the United States of America 107(20):9264-9269. 
653 Zhang J, Kapli P, Pavlidis P, Stamatakis A. 2013. A general species delimitation method with 654 applications to phylogenetic placements. Bioinformatics 29(22):2869-2876.

655 https://doi.org/10.1093/bioinformatics/btt499 


\section{Table legends}

657 Table 1. Names, museum codes, localities and GenBank accession numbers of sequences of 658 specimens of Centrolene buckleyi species complex analysed in this study. Sequences gathered 659 here are written in bold.

\section{Figure legends}

661 Figure 1. Distribution of Centrolene buckleyi species complex. Centrolene buckleyi sensu stricto 662 (KU 178031 Imbabura province, Ecuador and MZUTI 763 Napo province, Ecuador, blue 663 circles); C. buckleyi [Ca1] Shucos, Zamora province, Ecuador (orange circle); C. buckleyi [Ca2] 664 Yanayacu, Napo province, Ecuador (green circle); C. aff. buckleyi [Ca3] MAR 371 Chingaza 665 National Park, Cundinamarca, Colombia (purple circle); C. venezuelense EBRG 5244 Páramo de 666 Maraisa, Mérida, Venezuela (red circle). C. ballux in Ecuador (black triangle) and C. sabini in 667 Peru (black star).

668 Figure 2. ML tree depicting phylogenetic relationships of species of the genus Centrolene based 669 on the concatenated dataset of $12 S+16 S$ sequences. Gray nodes represent Bayesian posterior 670 probabilities equal or greater than 0.95 and ML bootstrap values equal or greater than $75 \%$.

671 Species names with different colours represent lineages within the Centrolene buckleyi species 672 complex.

673 Figure 3. Maximum clade credibility of DNA sequences of glassfrogs of the genus Centrolene 674 based on mitochondrial DNA (12S and 16S) showing a comparison of the results of distinct 675 species delimitation methods (see text for details). Each coloured bar represents a candidate 676 species delimited by each method employed. The calibrated gene tree is from a BEAST 2 
677 analysis under a relaxed clock with a Birth-Death model tree prior. Node height was determined

678 using mean height across the posterior distribution. Asterisks above branches represent Bayesian

679 posterior probabilities equal or greater than 0.95 . The outgroup (Nymphargus) was removed prior

680 to the analyses. Figure inserted in the upper left end corresponds to log lineages through time

681 plot, which shows an increase in the rates of branching to the present, probably corresponds to

682 the change from interspecific to intraspecific branching events. 
Figure 1

Distribution of Centrolene buckleyi species complex.

Centrolene buckleyi sensu stricto (KU 178031 Imbabura province, Ecuador and MZUTI 763 Napo province, Ecuador, blue circles); C. buckleyi [Ca1] Shucos, Zamora province, Ecuador (orange circle); C. buckleyi [Ca2] Yanayacu, Napo province, Ecuador (green circle); C.aff. buckleyi [Ca3] MAR 371 Chingaza National Park, Cundinamarca, Colombia (purple circle); C. venezuelense EBRG 5244 Páramo de Maraisa, Mérida, Venezuela (red circle). C. ballux in Ecuador (black triangle) and C. sabini in Peru (black star).

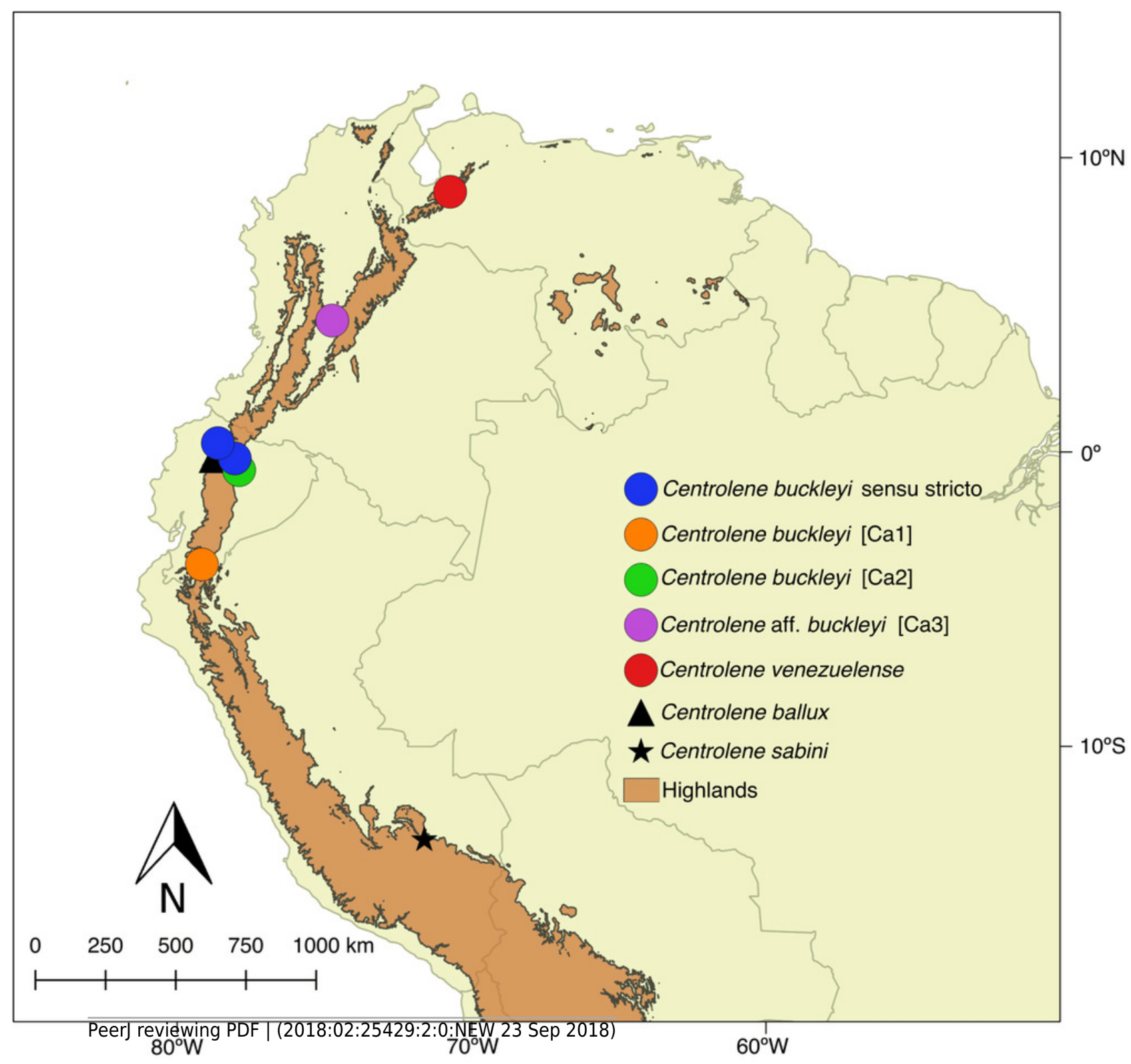




\section{Figure 2 (on next page)}

ML tree depicting phylogenetic relationships of species of the genus Centrolene based on the concatenated dataset of $12 S+16 S$ sequences.

Gray nodes represent Bayesian posterior probabilities equal or greater than 0.95 and ML bootstrap values equal or greater than $75 \%$. Species names with different colours represent lineages within the Centrolene buckleyi species complex. 


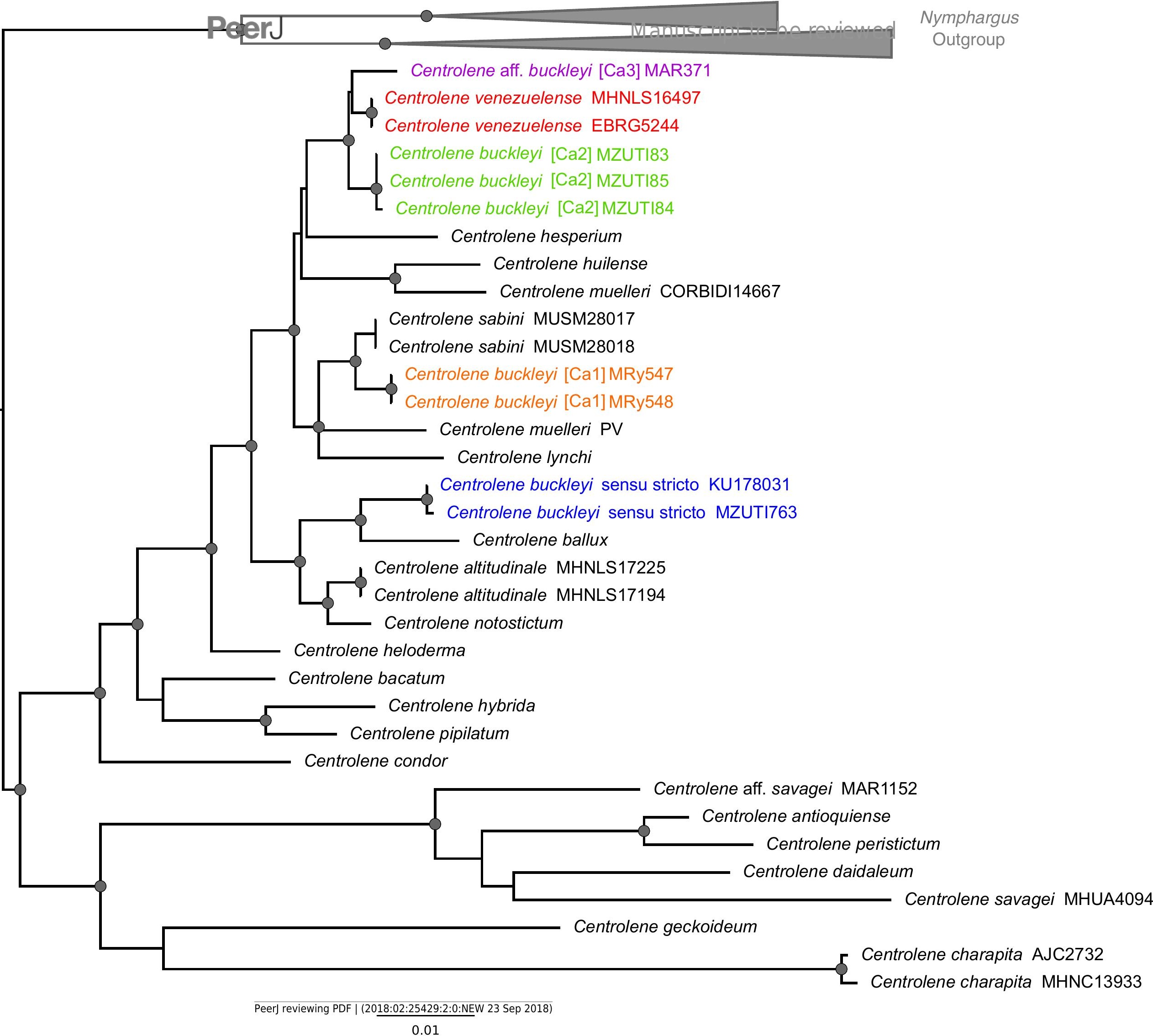




\section{Figure 3 (on next page)}

Maximum clade credibility of DNA sequences of glassfrogs of the genus Centrolene based on mitochondrial DNA (12S and 16S) showing a comparison of the results of distinct species delimitation methods (see text for details).

Each coloured bar represents a candidate species delimited by each method employed. The calibrated gene tree is from a BEAST 2 analysis under a relaxed clock with a Birth-Death model tree prior. Node height was determined using mean height across the posterior distribution. Asterisks above branches represent Bayesian posterior probabilities equal or greater than 0.95 . The outgroup (Nymphargus) was removed prior to the analyses. Figure inserted in the upper left end corresponds to log lineages through time plot, which shows an increase in the rates of branching to the present, probably corresponds to the change from interspecific to intraspecific branching events. 


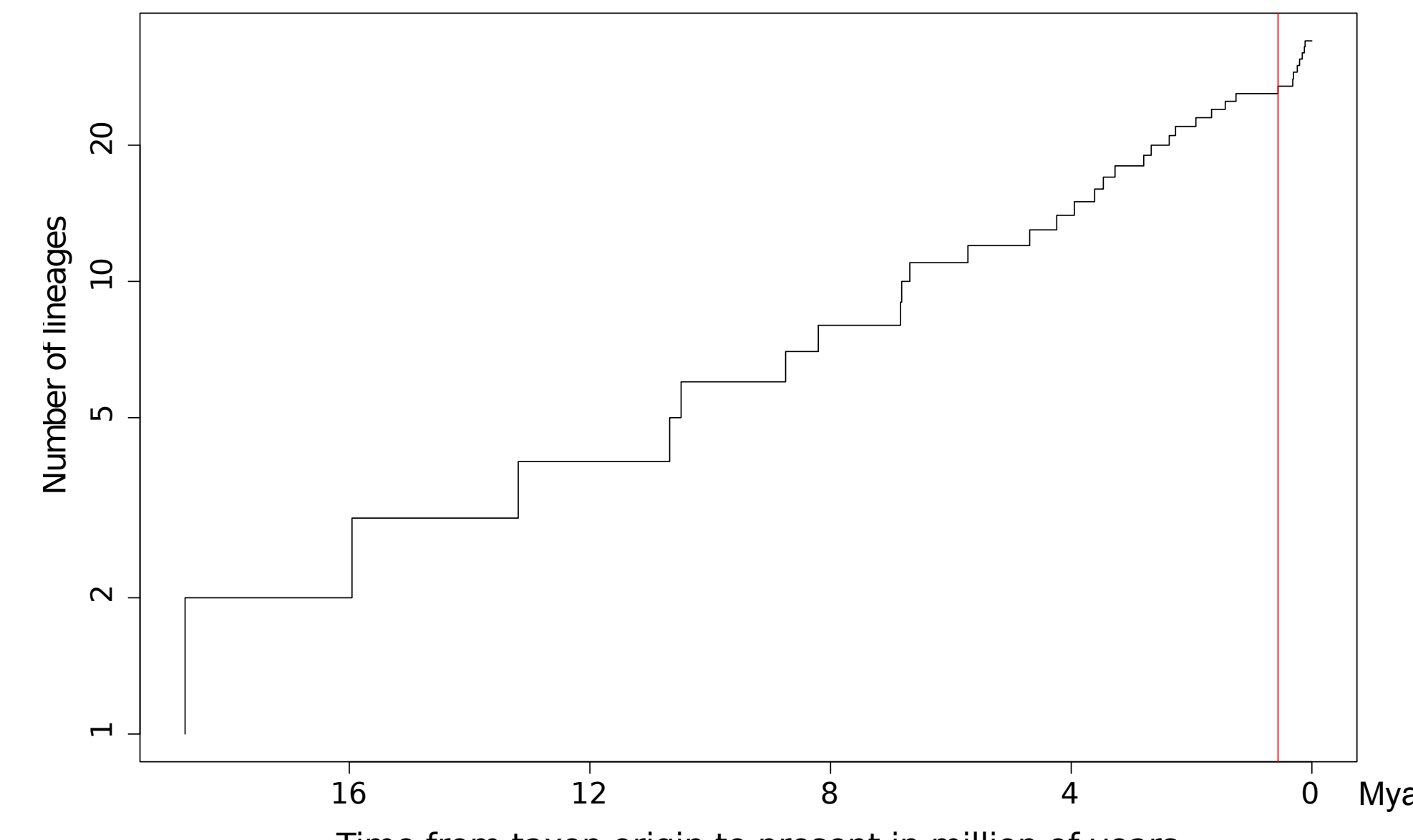

Time from taxon origin to present in million of years
- Centrolene aff. buckleyi [Ca3]MAR371 Centrolene venezuelense MHNLS

* [ Centrolene venezuelense EBRG5244 [ Centrolene buckleyi [Ca2] MZUTI83 [ Centrolene buckleyi [Ca2] MZUTI85

L Centrolene buckleyi [Ca2] MZUTI84 Centrolene hesperium MHNSM25802

Centrolene huilense Q37230

Centrolene muelleri CORBIDI14667

Centrolene lynchi

Centrolene muelleri PV

Centrolene sabini MUSM28017

Centrolene sabini MUSM28018

Centrolene buckleyi [Ca1] MRy547

Centrolene buckleyi [Ca1] MRy548

Centrolene altitudinale MHNLS17225

Centrolene altitudinale MHNLS17194

Centrolene notostictum MAR510

Centrolene ballux

Centrolene buckleyi s.s. KU178031

Centrolene buckleyi s.s. MZUTI763

Centrolene heloderma Q40200

Centrolene bacatum

Centrolene hybrida MAR347

Centrolene pipilatum KU178154

Centrolene condor Q44896

- Centrolene charapita AJ C2732

- Centrolene charapita MHNC13933

Centrolene geckoideum

Centrolene aff. savagei MAR1152

Centrolene antioquiense NRPS014

Centrolene peristictum

Centrolene daidaleum

Centrolene savagei MHUA4094

0 Mya

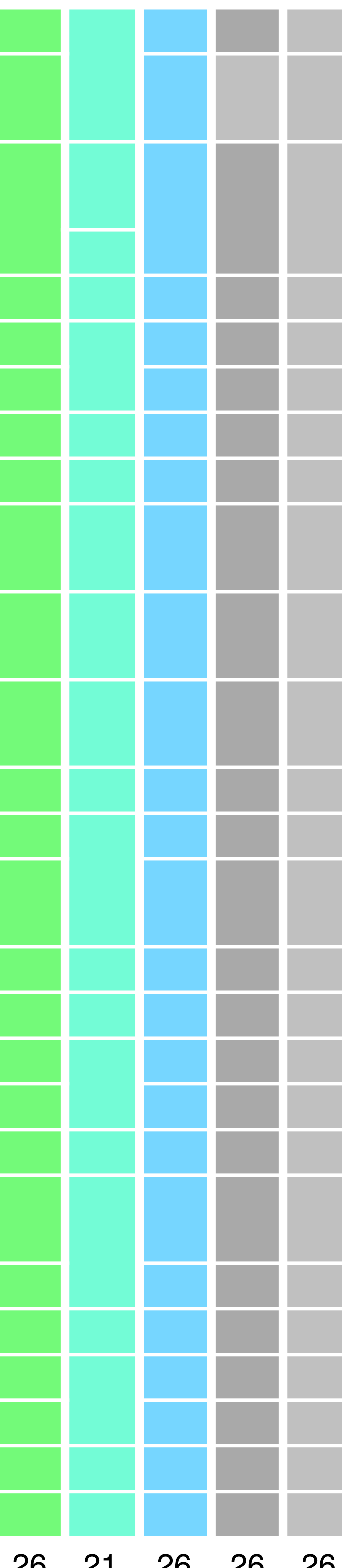

$\begin{array}{lllll}26 & 21 & 26 & 26 & 26\end{array}$ 


\section{Table $\mathbf{1}$ (on next page)}

Names, museum codes, localities and GenBank accession numbers of sequences of specimens of Centrolene buckleyi species complex analysed in this study.

Sequences gathered here are written in bold. 
Table 1. Names, museum codes, localities and GenBank accession numbers of sequences of specimens of Centrolene buckleyi species complex analysed in this study. Sequences gathered here are written in bold.

\begin{tabular}{|c|c|c|c|c|c|c|c|c|}
\hline Specie/Taxon & $\begin{array}{l}\text { Museum } \\
\text { code }\end{array}$ & $\begin{array}{l}\text { GenBank } \\
\text { number } 12 S\end{array}$ & \begin{tabular}{|l|} 
GenBank \\
number $16 S$
\end{tabular} & Latitude & Longitude & $\begin{array}{l}\text { Elevation } \\
\text { msnm }\end{array}$ & Locality & Country/State \\
\hline $\begin{array}{l}\text { Centrolene } \\
\text { buckleyi s.s }\end{array}$ & $\begin{array}{l}\text { KU } \\
178031\end{array}$ & EU663338 & EU662979 & 0.3025 & -78.6186 & 3010 & $\begin{array}{l}\text { cerca a Lago } \\
\text { Cuicocha }\end{array}$ & $\begin{array}{l}\text { Ecuador. } \\
\text { Imbabura }\end{array}$ \\
\hline $\begin{array}{l}\text { Centrolene } \\
\text { buckleyi s.s }\end{array}$ & $\begin{array}{l}\text { MZUTI } \\
763\end{array}$ & MH844843 & MH844849 & -0.2189 & -78.0444 & 3012 & $\begin{array}{l}\text { Zona de humedal } \\
\text { en camino } \\
\text { Oyacachi-El Chaco }\end{array}$ & Ecuador. Napo \\
\hline $\begin{array}{l}\text { Centrolene } \\
\text { buckleyi [Ca1] }\end{array}$ & MRy 547 & MH844838 & MH844844 & -3.8193 & -79.1592 & 2633-2923 & Shucos & $\begin{array}{l}\text { Ecuador. } \\
\text { Zamora } \\
\text { Chinchipe }\end{array}$ \\
\hline $\begin{array}{l}\text { Centrolene } \\
\text { buckleyi [Ca1] }\end{array}$ & Mry 548 & MH844839 & MH844845 & -3.8193 & -79.1592 & 2633-2923 & Shucos & $\begin{array}{l}\text { Ecuador. } \\
\text { Zamora } \\
\text { Chinchipe }\end{array}$ \\
\hline $\begin{array}{l}\text { Centrolene } \\
\text { buckleyi [Ca2] }\end{array}$ & MZUTI 83 & MH844840 & MH844846 & -0.6133 & -77.8974 & 2187-2190 & Yanayacu & Ecuador. Napo \\
\hline $\begin{array}{l}\text { Centrolene } \\
\text { buckleyi [Ca2] }\end{array}$ & MZUTI 84 & MH844841 & MH844847 & -0.6133 & -77.8974 & 2187-2190 & Yanayacu & Ecuador. Napo \\
\hline $\begin{array}{l}\text { Centrolene } \\
\text { buckleyi [Ca2] }\end{array}$ & MZUTI 85 & MH844842 & MH844848 & -0.6133 & -77.8974 & 2187-2190 & Yanayacu & Ecuador. Napo \\
\hline $\begin{array}{l}\text { Centrolene aff. } \\
\text { buckleyi [Ca3] }\end{array}$ & MAR 371 & EU663339 & EU662980 & 4.4660 & -74.7333 & 3035 & $\begin{array}{l}\text { Sitio Monte } \\
\text { Redondo.P.N. } \\
\text { Chingaza }\end{array}$ & $\begin{array}{l}\text { Colombia. } \\
\text { Cundinamarca }\end{array}$ \\
\hline $\begin{array}{l}\text { Centrolene } \\
\text { venezuelense }\end{array}$ & $\begin{array}{l}\text { EBRG } \\
5244\end{array}$ & EU663359 & EU663000 & 8.8419 & -70.7311 & 2450 & $\begin{array}{l}\text { Páramo de } \\
\text { Maraisa }\end{array}$ & $\begin{array}{l}\text { Venezuela. } \\
\text { Mérida }\end{array}$ \\
\hline $\begin{array}{l}\text { Centrolene } \\
\text { venezuelense }\end{array}$ & $\begin{array}{l}\text { MHNLS } \\
16497\end{array}$ & EU663360 & EU663001 & 8.7092 & -70.9822 & $\begin{array}{r}2100 \\
3050\end{array}$ & $\begin{array}{l}\text { Cordillera de } \\
\text { Mérida }\end{array}$ & $\begin{array}{l}\text { Venezuela. } \\
\text { Mérida }\end{array}$ \\
\hline
\end{tabular}

4 